удк 629.027.2.678.063

https://doi.org/10.37700/enm.2019.4(14).18-24

\title{
Аналіз протекторів колісних систем сільськогосподарського призначення
}

\author{
К.В. Крутас ${ }^{1}$, Р.В. Антощенков ${ }^{2}$ \\ Харківський національний технічний університет сільського господарства \\ ім. П. Василенка (м. Харків, Україна) \\ email: ${ }^{1}$ kostykkrutas@gmail.com, 2 roman.tiaxntusg@gmail.com; \\ ORCID: ${ }^{1}$ 0000-0001-7909-3200, ${ }^{2}$ 0000-0003-0769-7464
}

\begin{abstract}
Пошук чинних напрямів дослідження для підвищення ефективності сільськогосподарських агрегатів, за допомогою оптимізації колісних пар, малюнка протектора та певного рівня тиску у шинах транспортних агрегатів. Попередній досвід свідчить про те, що при використанні важких сільськогосподарських машин та тракторів на полях нерідко дає негативний ефект і приводить до пагубної дії на ґрунт. В сільськогосподарський техніці використовується багато різних колісних систем. Для кожного окремого випадку наприклад для різних ґрунтів, доріг, різних погодних умов, різних агрегатів потрібно використовувати різні параметри для колісних систем. Такі параметри як: різний рівень тиску в повітряних камерах коліс, різні малюнки на протекторі колеса, змінювати висоту малюнка протектора колеса для покращення рівню прохідності. Малюнок протектора відіграє одну з найголовніших ролей в процесі щоденної експлуатації сільськогосподарської техніки. Він впливає на прохідність по ґрунту після атмосферних опадів, самоочищення та бокову стійкість. Для важкої сільськогосподарський техніці бажано використовувати такі малюнки протектора, як: «ялинка», «ключка» та багато-блоковий протектор. Встановлено, що протидіяти ущільненню ґрунту, а також там де вкрай небажано його пошкоджувати, і потрібна рівна поверхня та недопустимість дефектів використовується шини з низьким тиском. Встановлено, що залишається недостатньо досліджено вплив геометричних параметрів колісних систем та їх ефективності. У зв'язку чим необхідно розробити комплекс заходів, що спрямовані на збереження родючості ґрунтів. Таким чином треба ще звертати увагу на економічні показники використовування колісних пар. Дана проблема є досі актуальною для сільського господарства України.
\end{abstract}

Ключові слова: протектор, колесо, сільськогосподарська техніка, трактор.

Вступ. Одним з важливих чинників, який обмежує зростання і врожайність сільськогосподарських культур, є надмірне ущільнення ґрунту. Одним з основних напрямів підвищення ефективності виробництва в рослинництві є комплексна механізація технологічних процесів і впровадження передових технологій з використанням універсальних і екологічних машин.

Однак, використання на полях важкої сільськогосподарської техніки, призводить до переущільнення ґрунту, знижує її родючість i, як наслідок, різко знижує врожайність сільськогосподарських культур. Необхідність підвищення рівня стану сільськогосподарського виробництва висуває в число найбільш актуальних проблем завдання поліпшення показників роботи ходових систем мобільної колісної сільськогосподарської техніки - тракторів, комбайнів та сільськогосподарських машин.

Вирішення цієї проблеми приводить до зниження ущільнюючого впливу на ґрунт колісних систем до допустимого рівня, зменшення опору руху машин, підвищення тяго-зчіпних властивостей та ін.

Аналіз останніх досліджень і публікацій та постановка цілей. Теоретичний і експериментальний матеріал по механізації рослинництва, накопичений на сьогоднішній день за кордоном, свідчить про те, що застосування колісних тракторів як енергетичних засобів на полях нерідко надає негативний ефект i призводить до зниження врожайності сільськогосподарських культур, необоротної пагубної дії на ґрунт [1]. Дослідженнями встановлено, що тільки близько 12\% площі полів не схильне до впливу рушіїв, а сумарна площа слідів рушіїв більш ніж в два рази перевищує площу поля. Зниження врожаю з цієї причини досягає за різними даними від 20 до 40\% [2].

Тягово-зчіпні якості визначають продуктивність машинно-тракторного агрегату (МТА), витрату палива та залежать від несприятливих погодних умов. Вплив на рушіїв ґрунт найважливіший показник для трактора, так як він безпосередньо впливає на врожайність та визначає енерговитрати на подальшу обробку полів $[1,3]$. Плавність ходу також відноситься до основних функціональних характеристик рушіїв, так як саме вона обмежує швидкість агрегату, визначає якість польових робіт і комфортність умов праці механізатора, рівень вібраційного навантаження вузлів машини [2]. 
Численними дослідженнями встановлено вплив коліс трактора на експлуатаційно-технологічні показники роботи МТА: зниження продуктивності і прохідності підвищення питомої витрати палива; знос шин; негативний вплив на фрізико-біологічні властивості ґрунту (відхилення від оптимальних характеристик ґрунтів, таких як твердість, пористість, структура, щільність).

Не зважаючи на чисельну кількість попередніх робіт залишається недостатньо досліджено вплив геометричних параметрів колісних систем та ефрективності. У зв'язку з необхідністю розробки комплексу заходів, спрямованих на збереження родючості ґрунтів, можна зробити висновок, що дана проблема $є$ досі актуальною для сільського господарства.

Метою роботи $€$ аналіз протекторів колісних систем сільськогосподарського призначення для обґрунтування шляхів енергоефективної експлуатації та подальшої оптимізації колісних пар.

Основна частина. Збереження родючості ґрунтів - глобальне завдання і в її вирішенні велика роль рушіїв польової техніки. До сільськогосподарського рушія пред'являються особливі вимоги, так як він взаємодіє з ґрунтом, який є опорним і оброблюваним матеріалом. Він є складним біо-мінеральним середовищем. Ущільнення ґрунту і інтенсивне перетирання його структурних складових в результаті буксування, негативно позначається на родючості, супроводжує розвиток ерозії, веде до деградації ґрунтів.

В першу чергу істотно погіршуються основні фрізичні і технологічні властивості орного i підорного шарів ґрунту і знижується родючість. Погіршується структурний стан ґрунту, внаслідок руйнування не тільки макро, але і мікроструктурних агрегатів, підвищується вміст пилу в орному шарі. У колії тракторів різко зростає щільність і твердість.

Утворена колія ускладнює в подальшому роботу сільгоспмашин, викликає нерівномірність закладення насіння, знижує їх польову схожість, обумовлює багато-ярусність посівів і неодночасність їх дозрівання. Це в кінцевому підсумку веде до зниження врожаю сільськогосподарських культур.

Зниження врожайності відбувається не тільки в рік ущільнення, а й в наступні: 2-й і 3-й роки, так як процеси розущільнення орного і підорного шарів проходять протягом декількох років. Для усунення ущільнення підорного шарів потрібна додаткова обробка, пов'язана зі значними енерговитратами.

Для зменшення негативного впливу ходових систем МТА застосовуються технологічні, агрономічні та конструкторські заходи.

Технологічні заходи: зниження числа проходів сільськогосподарської техніки по полях, сумі- щені технології, раціональна маршрутизація руху, застосування комбінованих і широкозахватних агрегатів, мінімальної обробки ґрунту, використання перевантажувальної технології при взаємодії з транспортними засобами.

Агрономічні - підвищення здатності ґрунту протистояти ущільнюючим і руйнуючим навантаженням завдяки внесенню добрив (органічних), введення додаткової операції зниження ущільнення ґрунту (шляхом глибокого чизелювання, глибокої оранки і оранки 3 смуговим розпушуванням).

Конструкторські - вдосконалення тракторів і сільгоспмашин, їх рушіїв, зниження їх матеріаломісткості, застосування рушіїв зі збільшеною опорною поверхнею, підвищення їх тягово-зчіпних властивостей. Погіршення останніх веде до зниження робочої швидкості, збільшення витрати палива, підвищення зношуваності елементів трансмісії і ходової системи через підвищення буксування.

Конструкторський напрямок є найбільш ефективним заходом вирішення проблеми переущільнення ґрунту, так як легше і дешевше запобігти механічному впливу рушіїв на ґрунт, ніж потім усувати його наслідки. Слід також зазначити, що агрономічний напрямок хоча і знижує негативний вплив переущільнення ґрунтів, але не може усунути його повністю.

Отже, основною повинна бути задача щодо вдосконалення рушіїв, а також аналіз впливу тиску на ущільнення ґрунту, ходовою системою тракторів та сільськогосподарськими машинами, оскільки вимоги, що пред'являються сьогодні до ходових систем машин, випливають із загальних вимог охорони навколишнього середовища, що включають забезпечення схоронності ґрунту і її родючості.

Під час контакту шини з поверхнею (асфальтобетон, цементобетонну та ін.) площа плями контакту залежить від величини нормального навантаження $G_{\text {к }}$ і радіальної жорсткості шини $C_{ш}$. При цьому слід розрізняти контурну площу плями і площу по виступах протектора (рис. 1)

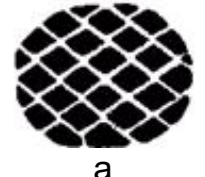

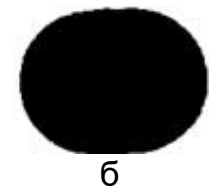

б
Рис. 1. Площа плями контакту (а - по виступах, б - контурну)

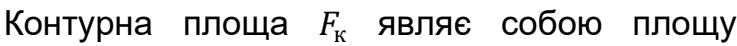
фігури, утвореної замкненою лінією, що обгинає зону контактування виступів протектора 3 опорною площиною, а площа по виступам $F_{\mathrm{B}}-$ 
суму площ фрактичних зон контактування виступів з опорною поверхнею. При взаємодії колеса з твердою опорною поверхнею контурна площа плями контакту значно більше площі по виступах, тому що включає всі проміжки між виступами протектора. Визначення зазначених площ називається коефіцієнтом насиченості контакту та визначається:

$$
K_{H}=\frac{F_{B}}{F_{K}}
$$

Контурна площа плями контакту може бути наближено знайдена за формулою, що запропонована Р. Хедекелем [3]:

$$
F_{K}=\pi h_{z} \sqrt{D_{C B} b},
$$

де $D_{C B}, b$ - відповідно вільний діаметр і ширина профілю шини; $h_{z}$ - радіальна деформація шини.

Величина радіальної деформації $h_{z}$ визначається:

$$
h_{z}=\frac{G_{K}}{c_{\Psi}} .
$$

Радіальна жорсткість, в свою чергу, залежить від конструкції шини, геометричних розмірів і внутрішнього тиску повітря. Її значення може бути виражене емпіричної формулою:

$$
c_{\amalg}=\pi k\left(p_{W}+p_{0}\right)^{\sqrt{D_{C B} b}},
$$

де $p_{W}$ - внутрішній тиск повітря в шині; $p_{0}$ - тиск в плямі контакту при $p_{W}=0 ; k$ - емпіричний коефріцієнт.

При коченні колеса по ґрунту мають місце такі дефрормації опорної поверхні:

- зминання і ущільнення ґрунту;

- видавлювання ґрунту в сторони;

- переміщення ґрунту у напрямку руху;

- відрив поверхневого шару ґрунту внаслідок його прилипання до шини;

- зріз протектором поверхневого шару ґрунту та його викидання з зони контакту (ефект «екскавації» при пробуксовуванні колеса).

Робота по зминанню ґрунту колесом за один оборот (рис. 2) дорівнює роботі по деформації рунту шириною $b$, висотою $h$ і довжиною $S=2 \pi R \kappa$

Поділивши величину навантаження $G_{\text {к }}$ на площу $F_{\text {к }}$, отримаємо фрормулу, яка має середній тиск шини по контуру плями контакту (рис. 1,б):

$$
P_{\Psi_{-} C P}=\frac{G_{K}}{F_{K}}=k p_{W}+p_{0} .
$$

Величину роботи зминання можна виразити формулою:

$$
A_{r}=S b^{\int_{0}^{h} f(h) d h},
$$

де $f(h)$-залежність нормального тиску колеса на ґрунт від глибини колії (деформованість ґрунту).

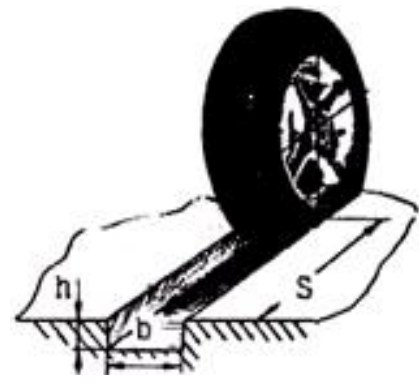

Рис. 2. Зминання ґрунту колесом

За один оборот колеса робота сили опору коченню:

$$
A_{f}=P_{f} S \text {. }
$$

Якщо прийняти, що $A_{f}$ дорівнює роботі по деформації ґрунту $A_{\Gamma}$, то, прирівнявши $A_{f}$ і $A_{\Gamma}$ та поділивши обидві частини рівності на $S$ та $G_{K}$, отримаємо фрормулу ко159ефіцієнта опору коченню, який пов'язаний зі зминанням ґрунту:

$$
f_{\Gamma}=\frac{b c}{(\mu+1) G_{K}} h^{\mu+1},
$$

де $c, \mu-$ постійні коефіцієнти, які визначаються імперічно.

При певних параметрах ґрунту, ширині колеса і навантаженні, коефіцієнт опору коченню нелінійно залежить від глибини колії і зі збільшенням останньої зростає.

В сільськогосподарській техніці використовується багато різних протекторів колісних систем. Для кожного окремого випадку, наприклад, для різних ґрунтів, доріг, різних погодних умов, різних агрегатів потрібно використовувати різні параметри. Наприклад різні малюнки протектора колеса, покращують рівень прохідності, та знижають питомий тиск на ґрунт[3].

У техніці зараз використовується дуже багато коліс для різних ґрунтів. Найвідоміші виробники BKT, Nohia, Michelin, Pronar, ADR та ін. Але всі вони просто випускають продукцію без урахування щодо їх використання у різних умовах (твердий ґрунт, суглинки, чорнозем). Однак малюнок протектора колеса відіграє значну роль в процесі щоденної експлуатації сільськогосподарської техніки [4].

Продуктивність машин залежить від типу шини і малюнка її протектора [4]. У класичній сільськогосподарській практиці необхідно виконувати різні види операцій, такі як обробка ґрунту, внесення добрив та ін., сівба, збирання врожаю. Використання сільськогосподарського транспорту необхідно протягом усього виробничого циклу. Цей цикл операцій повторюється і на наступний сезон. Тому кожна технологічна операція має свої унікальні вимоги до коліс за для підвищення продуктивності машини і загальної врожайності. 
Таким чином, при проектуванні шин для сільськогосподарського призначення, особлива увага повинна бути приділена важливим критеріям, таким як малюнок у протектора та глибині протектора, кут і кількість ґрунтозачепів.

Правильний вибір дизайну протектора може істотно підвищити ефективність сільськогосподарських робіт [1,5].

Відповідно до міжнародних стандартів існують три основні моделі проекторів і їх конструкції: «ребро», що ідеально підходить для рульових осей і малих сільськогосподарських знарядь; блоковий тип, що є найбільш ефективним для транспортування; тип «ґрунтозачепи», що найкраще підходить для польових операцій.

Основною характеристикою дизайну типу «ґрунтозачепи» з нульовим кутом (рис. 3, а) відмінна та курсова стійкість, але він забезпечує мінімальну тягу або ії̈ повну відсутність. Дизайн типу «ґрунтозачепи» $390^{\circ}$ (рис. 3, б) забезпечує максимальну тягу, а також має найменший опір кочення, і як наслідок, зменшує витрату палива. Низький комфорт є недоліком для шин з таким типом дизайну. Оптимальний дизайн для коліс сільськогосподарського призначення «ґрунтозачепи» (рис. 3, в). Він представляє собою компроміс попередніх ґрунтозачепів.

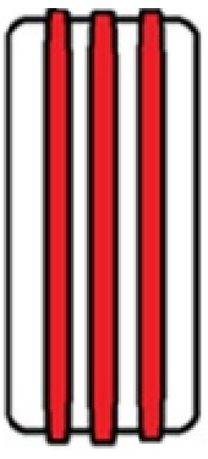

a

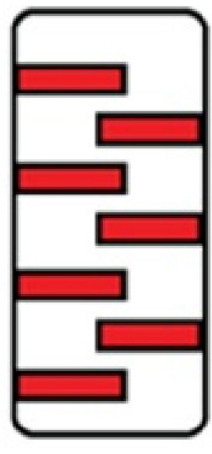

6

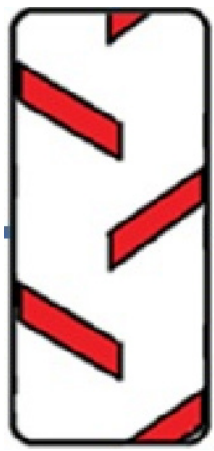

Рис. 3. Ґрунтозачепи нульовий кут (а), 90 (б), комбінований (в)

Реберний протектор використовується задля керованих коліс причіпної сільськогосподарської техніки (рис. 4). Забезпечує відмінну курсову стійкість і зчеплення навіть на сипучій кам'янистій поверхні, знижує боковий увід, та має велику несучу здатність.

Вузлуватий або багато-блоковий протектор (рис. 5) можна встановити, як на провідні колеса, так і на відомі колеса сільськогосподарської техніки. Такі покришки є кращім вибором для м'яких типів ґрунтів тому, що вони завдають мінімальної шкоди ґрунту. Вони мають меншу несучу здатність ніж колеса з ребристим протектором.

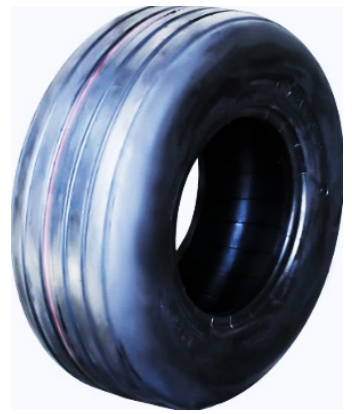

Рис. 4. Ребристий протектор

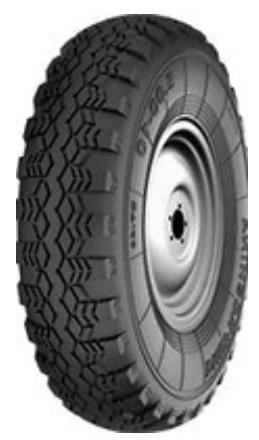

Рис. 5 Багато-блоковий протектор

Спрямований протектор «ялинка» (рис. 6) встановлюється на ведучі колеса, як правило на ведучі колеса тракторів та розприскувачів, причепів сільськогосподарської техніки і забезпечує високу прохідність на різних ґрунтах й погодних умовах.

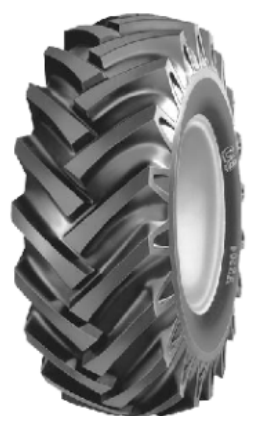

Рис. 6. Спрямований протектор «ялинка»

Протектори «ключка» (рис. 7) ефективно використовувати на м'яких ґрунтах. Ще одною з важливих характеристик «ключки» $є$ посилена боковина, стійкість до порізів та пробоїв. Ступінчастий протектор забезпечує високі тягові характеристики. Цей малюнок протектора поєднує грунтозачепи з кутом $90^{\circ}$ та $45^{\circ}$ («ялинка»). Тому він забезпечує підвищення тяги та прохідність одночасно.

Але не тільки від малюнка протектора залежить ущільнення різних типів ґрунту, а ще й від внутрішнього тиску. $Є$ шини низького та високого тиску які потрібно використовувати для різних умов. 


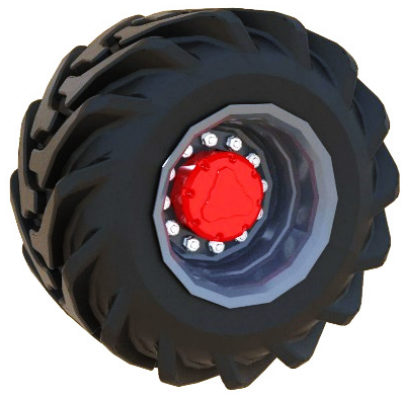

Рис. 7. Протектор «Ключка»

Шини високого тиску наразі не використовуються у сільськогосподарському виробництві.

Шини низького тиску найчастіше використовуються на сільськогосподарській техніці на м'якому ґрунті через те, що такий вид ґрунту особливо нестійкий до стресових навантажень, і важка техніка може значно вплинути на його стан (родючість та інші важливі характеристики) [5].

Шини низького тиску менше травмують ґрунт. Завдяки своїм характеристикам, вони мають низький питомий тиск опору на поверхню, розподіляючи рівномірно навантаження по всій площі. Дані шини ідеально підходять для роботи техніки в делікатних умовах, максимально обережно взаємодіючі з робочою поверхнею.

Знижений тиск позитивно впливає на плавність ходу. Досягається воно завдяки тому, що шина низького тиску має більший об'єм повітряної камери. Підвищення об'єму відбувається за рахунок звеличення розміру шини- збільшення ширини профілю, що зменшує тиску на опорну поверхню.

Високий рівень прохідності техніки потребує використання шин низького тиску Саме такі шини використовуються на будівельних роботах, пов'язаних з водними ресурсами, де часто бувають випадки активного зсуву ґрунту. У таких випадках використовуються шини зниженого тиску з малюнком «ялинка», та «ключка». Завдяки цьому збільшуються зчеплення та стійкість машини на проблемному ґрунті.

Також, шини низького тиску активно використовуються при роботах на торф'яних ґрунтах і на спецтехніці в лісових зонах, де сама місцевість $€$ болотистою.

Важливо розуміти, що шини для сільськогосподарської техніки, які оптимальні для використання під час збиральних робіт, не можна використовувати для сівби. Коректне підібрані шини для сільгосптехніки - гарантія надійного і продуктивного використання сільськогосподарських машин без шкоди ґрунту і врожаю.

Позапланова заміна шини для сільгосптехніки - це додаткові непередбачені витрати.

\section{Висновки.}

1. Встановлено, що залишається недостатньо досліджено вплив геометричних параметрів колісних систем та їх ефрективності. У зв'язку чим необхідно розробити комплекс заходів, що спрямовані на збереження родючості ґрунтів. Дана проблема є досі актуальною для сільського господарства України.

2. Визначено, що відповідно до міжнародних стандартів існують три основні моделі проекторів і їх конструкції: «ребро», що ідеально підходить для рульових осей і малих сільськогосподарських знарядь; блоковий тип, що є найбільш ефективним для транспортування; тип «ґрунтозачепи», що найкраще підходить для польових операцій.

3. Реберний протектор використовується для керованих коліс та причіпної сільськогосподарської техніки. Він забезпечує відмінну курсову стійкість i зчеплення навіть на сипучій кам'янистій поверхні, знижує боковий увід, має велику несучу здатність.

4. Встановлено, що спрямований протектор «ялинка» встановлюється на ведучі колеса, та як правило на ведучі колеса тракторів й розприскувачів, причепів сільськогосподарської техніки і забезпечує високу прохідність на різних ґрунтах.

3. Протектори «ключка» ефективно використовувати на м'яких ґрунтах. Ще одною з важливих характеристик «ключки» $€$ посилена боковина, стійкість до порізів та пробоїв. Ступінчастий протектор забезпечує високі тягові характеристики.

6. Шини низького тиску використовуються 3 легкими ґрунтами, а також там, де вкрай небажано його пошкоджувати (чорнозем). Також, такий тип шин застосовується на техніці, яка обслуговує спортивні поля, де важлива рівність поверхні і відсутність дефектів рельєфу.

7. Необхідно використовувати малюнки на протекторах такі як «ялинка» та «ключка» на різних поверхнях з урахуванням різноманітних факторів, які впливають на родючість ґрунту та економічність.

\section{Література}

1. Русанов В.А. Проблема переуплотнения почв движителями и эфрфективные ее пути решения / - М.: ВИМ, 1998. - 368с.

2. Мочунова М.А. «Обоснование параметров и управление работой колесных тракторов с учетом энергетических потерь при взаимодействии движителей с почвой» М.: Машиностроение, 2010. - 10 c.

3. Проходимость машин / В.А. Скотников. - Мн.: Наука и техника, 1982. - 328с.

4. Ревенко В.Ю. «Повышение эфрфективности машинно-тракторных агрегатов с колесными тракторами классов 1,4, 2 и 3 на основе оптимизации параметров движителей». - М, 2006. - 182 c. 
5. Белковский В. Р., Варивода В.И.Шины низкого давления для сельскохозяйственной техники. ЦНИИТЭИ нефтехим. М., 1985.

6. Белковский В. Н., Пачев В. П., Шкурко Г. А., Ищенко В. А., Русанов В. А. Методические указания по выбору параметров колесного движителя с допустимым по ГОСТ 26955-86 воздействием на почву. Днепропетровск - Москва: НИИКГШ ВИМ, 1989. - $18 \mathrm{c}$.

7. Агейкин Я. С. Вездеходные колесные и комбинированные движители (теория и расчет). М.: Машиностроение, 1972. 184 с

\section{Reference}

1. Rusanov, V. (1998). Problema pereuplotnenija pochv dvizhiteljami i jeffektivnye ee puti reshenija. Moscow: VIM, p.368.

2. Mochunova, M. (2010). Obosnovanie parametrov $i$ upravlenie rabotoj kolesnyh traktorov $s$ uchetom jenergeticheskih poter' pri vzaimodejstvii dvizhitelej s pochvoj. Moscow: Mashinostroenie. p.10

3. Skotnikov, V. (1982). Prohodimost' mashin. Minsk: Nauka i tehnika, p.328.

4. Revenko, V. (2006). Povyshenie jeffektivnosti mashinno-traktornyh agregatov $s$ kolesnymi traktorami klassov 1,4, 2 i 3 na osnove optimizacii parametrov dvizhitelej. Moscow: p. 182.

5. Belkovskij, V. and Varivoda, V. (1985). Shiny nizkogo davlenija dlja sel'skohozjajstvennoj tehniki. Moscow: CNIITJel neftehim.

6. Belkovski, V., Pachev, V., Shkurko, G., Ishhenko, V. and Rusanov, V. (1989). Metodicheskie ukazanija po vyboru parametrov kolesnogo dvizhitelja $s$ dopustimym po GOST 26955-86 vozdejstviem na pochvu.. Dnepropetrovsk Moscow: NIIKGSh - VIM, p.18.

7. Agejkin, V. (1972). Vezdehodnye kolesnye i kombinirovannye dvizhiteli (teorija $i$ raschet). Moscow: Mashinostroenie, p.184.

\section{Аннотация}

\section{Анализ протекторов колесных систем сельскохозяйственного назначения}

\section{К.В. Крутас, Р.В. Антощенков}

Поиск действующих направлений исследования для повышения эффеективности сельскохозяйственных агрегатов, с помощью оптимизации колесных пар, рисунка протектора и определенного уровня давления в шинах транспортных агрегатов. Предыдущий опыт свидетельствует о том, что при использовании тяжелых сельскохозяйственных машин и тракторов на полях нередко дают отрицательные эффректы и приводят к пагубным воздействиям на почву. В сельскохозяйственной технике используется много различных колесных систем. Для каждого отдельного случая, например, для различных почв, дорог, различных погодных условий, различных агрегатов нужно использовать различные параметры для колесных систем. Такие параметры как: разный уровень давления в воздушных камерах колес, различные рисунки на протекторе колеса, изменять высоту рисунка протектора колеса для улучшения уровня проходимости. Рисунок протектора играет одну из главных ролей в процессе ежедневной эксплуатации сельскохозяйственной техники. Он влияет на проходимость по грунту после атмосферных осадков, само-очистка и боковую устойчивость. Для тяжелой сельскохозяйственной техники желательно использовать такие рисунки протектора, как «елочка», «клюшка» и мульти-блоковый протектор. Установлено, что противодействовать уплотнению грунта, а также там, где крайне нежелательно его повреждать, и нужна ровная поверхность и недопустимости дефектов используются шины с низким давлением. Установлено, что недостаточно исследовано влияние геометрических параметров колесных систем и их эффективности. В связи чем необходимо разработать комплекс мероприятий, направленных на сохранение плодородия почв. Таким образом надо еще обращать внимание на экономические показатели использования колесных пар. Данная проблема до сих пор актуальна для сельского хозяйства Украины.

Ключевые слова: протектор, колесо, сельскохозяйственная техника, трактор.

Abstract

\section{Analysis of agricultural wheel system treads}

\section{K.V. Krutas, R.V. Antoshchenkov}

Finding the right areas of research to improve the efficiency of agricultural units by optimizing wheel pairs, tread pattern and a certain level of pressure in the tires of transport units. Previous experience has shown that heavy agricultural machinery and tractors often have a negative effect on the fields and lead to damaging

ISSN 2311-1828

http://enm.khntusg.com.ua
Інженерія природокористування, 2019, №4(14), с. 18 - 24

Engineering of nature management, 2019, \#4(14), p. 18 - 24 
effects on the soil. Many different wheel systems are used in agricultural machinery. For each case, for example, for different soils, roads, different weather conditions, different units, different parameters for wheel systems must be used. Such parameters as: different pressure levels in the air chambers of the wheels, different drawings on the wheel tread, change the height of the tread pattern to improve the level of patency. The tread pattern plays one of the most important roles in the daily operation of agricultural machinery. It affects soil patency after precipitation, self-cleaning and lateral stability. For heavy agricultural machinery, it is advisable to use tread patterns such as: "herringbone", "crutch" and multi-block tread. It has been found that counteracting soil compaction, as well as where it is extremely undesirable to damage it, requires a flat surface and impermissible defects using low pressure tires. It is established that the influence of the geometrical parameters of the wheel systems and their efficiency remains insufficiently investigated. Therefore, it is necessary to develop a set of measures aimed at preserving soil fertility. Thus, it is necessary to pay attention to the economic indicators of the use of wheel pairs. This problem is still relevant for Ukrainian agriculture.

Keywords: tread pattern, wheel, agriculture units, tractor.

\section{Бібліографічне посилання / Bibliography citation: Harvard}

Krutas, K. and Antoshchenkov, R. (2019) 'Analysis of agricultural wheel system treads', Engineering of nature management, (4(14), pp. 18 - 24.

Подано до редакції / Received: 28.11.2019 